\title{
Evaporative snout cooling system on the performance of lactating sows and their litters in a subtropical region
}

\author{
Sistema de resfriamento adiabático evaporativo conduzido por ductos \\ no desempenho de fêmeas suínas em lactação e suas leitegadas
}

\author{
Jonas Perin ${ }^{I}$ Thais Schwarz Gaggini ${ }^{I}$ Samuel Manica ${ }^{I}$ Diogo Magnabosco ${ }^{I}$ \\ Mari Lourdes Bernardi ${ }^{I I}$ Ivo Wentz ${ }^{I}$ Fernando Pandolfo Bortolozzo ${ }^{I^{*}}$
}

\section{ABSTRACT}

The aim of the study was to evaluate the influence of different temperature control systems on the voluntary feed intake (VFI), percentage of weight loss (PWL) and performance of lactating sows as well as on the weight of their piglets. Two systems were used: traditional temperature control system (TTCS) with curtain management and an evaporative snout cooling system (ESCS). The study was performed during the summer of 2011. After farrowing and at the weaning, 241 sows were weighed to evaluate the PWL during lactation. TTCS sows lost more weight $(5.3 \pm 0.9 \%$; $P<0.05)$ than ESCS sows $(2.2 \pm 0.9 \%)$.VFI was measured at intervals of four days in 32 primiparous and 39 multiparous sows. ESCS

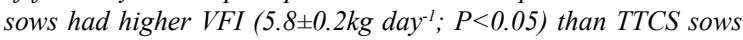
$\left(4.8 \pm 0.2 \mathrm{~kg}\right.$ day $\left.^{-1}\right)$. Primiparous sows $\left(4.4 \pm 0.2 \mathrm{~kg} \mathrm{day}^{-1}\right)$ had a lower VFI than multiparous sows $\left(6.3 \pm 0.2 \mathrm{~kg}\right.$ day $\left.{ }^{-1}, P<0.05\right)$ regardless of the temperature control system. Primiparous sows in the TTCS (10.9 \pm 1.3 days) had a longer weaning-to-oestrus interval than primiparous sows in the ESCS (7.0 11.2 days, $P<0.05)$. Subsequent litter size tended to be higher $(P=0.095)$ in ESCS than in TTCS (12.0 \pm 0.5 and $10.9 \pm 0.6$ piglets born, respectively). Litters housed in ESCS were heavier $(65.3 \pm 1.4 \mathrm{~kg} ; P<0.05)$ at weaning than litters in TTCS $(60.7 \pm 1.4 \mathrm{~kg})$. The results suggest that in general sows and piglets housed in the ESCS have better performance than sows and piglets housed in TTCS.

Key words: heat stress, piglet; weight, evaporative snout cooling system, temperature control, voluntary feed intake.

RESUMO

O objetivo do estudo foi avaliar a influência de diferentes sistemas de controle de temperatura sobre o consumo voluntário de ração (VFI), porcentagem de peso perdido (PWL) e desempenho de fêmeas lactantes e de suas leitegadas. Dois sistemas foram utilizados no estudo: o sistema tradicional de controle de temperatura (TTCS), com manejo de cortina e o sistema de resfriamento adiabático evaporativo (ESCS). O estudo foi realizado no verão de 2011. Após o parto e ao desmame, 241 fêmeas foram pesadas e foi avaliado o PWL durante a lactação. Fêmeas TTCS perderam mais peso $(5,3 \pm 0,9 \% ; P<0,05)$ do que as fêmeas ESCS $(2,2 \pm 0,9 \%)$. VFI foi medido em intervalos de quatro dias em 32 fêmeas primíparas e 39 multiparas. Fêmeas ESCS tiveram maior VFI $\left(5,8 \pm 0,2 \mathrm{~kg}^{-1}\right.$ dia; $\left.P<0,05\right)$ do que fêmeas TTCS $\left(4,8 \pm 0,2 \mathrm{~kg} \mathrm{dia}^{-1}\right)$. Primiparas $\left(4,4 \pm 0,2 \mathrm{~kg} \mathrm{dia}^{-1}\right)$ tiveram menor VFI

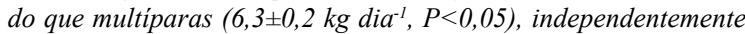
do sistema de controle de temperatura utilizado. Primíparas do TTCS $(10,9 \pm 1,3$ dias) tiveram maior intervalo desmame-estro do que primíparas do ESCS (7,0 $\pm 1,2$ dias, $P<0,05)$. O tamanho da leitegada do parto subsequente tendeu a ser maior $(P=0,095)$ no

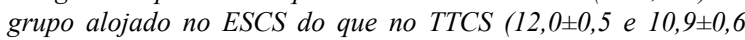
leitões nascidos, respectivamente). Leitegadas alojadas no ESCS foram mais pesadas $(65,3 \pm 1,4 \mathrm{~kg} ; \mathrm{P}<0,05)$ ao desmame do que no TTCS $(60,7 \pm 1,4 \mathrm{~kg})$. Os resultados observados sugerem que fêmeas e leitões alojados no ESCS apresentam melhor desempenho do que fêmeas e leitões alojados no TTCS.

Palavras-chave: estresse pelo calor, leitão, peso, sistema de resfriamento adiabático evaporativo, controle de temperatura, consumo voluntário de ração.

\section{INTRODUCTION}

Subtropical regions have approximately six months of heat, with temperature often exceeding $30^{\circ} \mathrm{C}$. This elevated temperature is far from the Thermal Comfort Zone (TCZ) of sows, which is between 12 and $22^{\circ} \mathrm{C}$ (BLOEMHOF et al., 2008). When environmental temperature is above the $\mathrm{TCZ}$, reproductive and productive performance

\footnotetext{
'Setor de Suínos, Faculdade de Veterinária, Universidade Federal do Rio Grande do Sul (UFRGS), Av. Bento Gonçalves, 9090, 91540-000, Porto Alegre, RS, Brasil. E-mail: fpbortol@ufrgs.br. "Corresponding author.

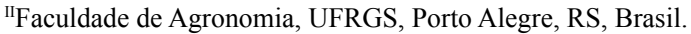


of sows may be impaired. High temperatures can cause direct and indirect consequences on herd performance, as pronounced decrease in voluntary feed intake (VFI), with consequent loss of body weight (QUINIOU \& NOBLET, 1999), increase in water intake (RENAUDEAU et al., 2003b), decrease in milk production (QUINIOU \& NOBLET, 1999), failures in subsequent reproductive performance of sows (THAKER \& BILKEI, 2005), increase piglet mortality by crushing and decrease piglet weight gain (MARTINS et al., 2008).

Production losses due to heat stress can be avoided by using some systems created to minimize the effects of high environmental temperature. For that purpose, there are systems of forced ventilation using fans (TOLON \& NÄÄS, 2005), evaporative snout cooling system (TOLON \& NÄÄS, 2005) and also with drip systems (BARBARI \& CONTI, 2009). However, the information concerning the performance of sows from different parities, when exposed to these systems, is scarce in regions of subtropical climate.

This study aimed to compare the influence of a traditional temperature control system (TTCS) that is widely used in subtropical productions systems, with an evaporative snout cooling system (ESCS), which lead cold air on sows' neck through ducts, on body temperature, VFI and percentage of weight loss (PWL) during lactation, and subsequent reproductive performance of sows as well as the weight gain of their litters.

\section{MATERIAL AND METHODS}

The study was performed in a pig farm with 5500 sows located in Santa Catarina state, Brazil (26 $6^{\circ} 22^{\prime} 13^{\prime \prime}$ south and $50^{\circ} 08^{\prime} 40^{\prime \prime}$ west). The climate in this region is subtropical and the trial was conducted during summer, in January and February of 2011. Pluviometric precipitation, average of relative humidity (RH) and variation of environmental temperature during the period of the study were $244.5 \mathrm{~mm}, 83.1 \%$ and 17.6 to $27.4^{\circ} \mathrm{C}$, respectively. A total of 249 Landrace $\mathrm{x}$ Large White/Duroc sows - Agroceres PIC $1062^{\circledR}$ (Agroceres PIC, Patos de Minas, MG, Brazil) and their litters were used in the study.

The farm has a total of 16 farrowing rooms with total capacity of 64 sows per room. Four farrowing rooms were used, being two with evaporative snout cooling system (ESCS) and two with the traditional temperature control system (TTCS). In the ESCS the air was conditioned by evaporative cooling pads, externally located on the west end of the room and connected to a curtain-like plastic duct (main duct) with $940 \mathrm{~mm}$ in diameter (DuctoFan, Cumberland ${ }^{\circledR}$, Marau, RS). The cooled air that came from the evaporative cooling pad was pushed by an axial fan into the main duct and thus conducted to the interior of the rooms. Inside the ESCS facilities, this duct was split into two independent ducts (secondary ducts) with $580 \mathrm{~mm}$ in diameter, located $3.0 \mathrm{~m}$ above the floor, one for each two rows of crates. From the two independent ducts, terminal individual ducts of $75 \mathrm{~mm}$ in diameter ended just above each farrowing crate, through which the air reached the sow's neck region (Figure 1). The ESCS was automatically turned on when the temperature of the facility became higher than $20^{\circ} \mathrm{C}$. ESCS was calibrated to have an output of cold air of $250 \mathrm{~m}^{3}$ hour ${ }^{-1}$. In addition to the ESCS, the curtains handling was also done. In the TTCS only curtains handling was used and the criteria to lift or descend the curtains were the same in both systems, following the standard operating procedure of the farm. It was taken into account the employee's perception related to aspects such as sun light incidence, thermal sensation, wind speed, age of piglets, air quality and amount of gases inside of the room. Crates had plastic floors, automatic feeders and water nipples. For the piglets there were creep boxes with heated floor and water nipples.

Sows were transferred to farrowing rooms 3-5 days before the expected parturition date. During lactation sows had ad libitum access to water and feed (a corn-soybean diet with $18.5 \%$ crude protein, $5.9 \%$ ether extract, $1.0 \%$ lysine and $3400 \mathrm{kcal} \mathrm{DE} \mathrm{kg}^{-1}$ ). Automatic feeders were used to store and control the amount of feed provided to the sows. Farrowing was assisted from the birth of the first piglet until total expulsion of foetal membranes.

After weaning, sows were transferred to gestation facilities, in individual crates which had slatted concrete floors, and were equipped with automatic feeders and water nipples. Oestrus detection was performed twice a day by the standing reflex in the presence of a mature boar. Sows were inseminated with doses containing $3 \times 10^{9}$ sperm cells at 0,24 and at $48 \mathrm{~h}$ after oestrus onset until they were no longer in standing oestrus.

From 249 sows housed, 8 were excluded from the analysis (six sows discarded by agalactia, one died, and one had a rectal prolapse). Thus, 241 sows of parities 1 to 8 were weighed at postpartum and at weaning and their PWL was calculated. The experiment occurred in two periods that started a week apart. One-hundred-twenty sows were housed during the first period (59 in the TTCS and 61 in the ESCS) and 121 were housed during the second period (63 and 58 in TTCS and ESCS, respectively).

A subsample of 71 sows was evaluated for the VFI and the performance of their litters (32 primiparous and 39 multiparous sows, equally distributed between ESCS and TTCS). Control of 


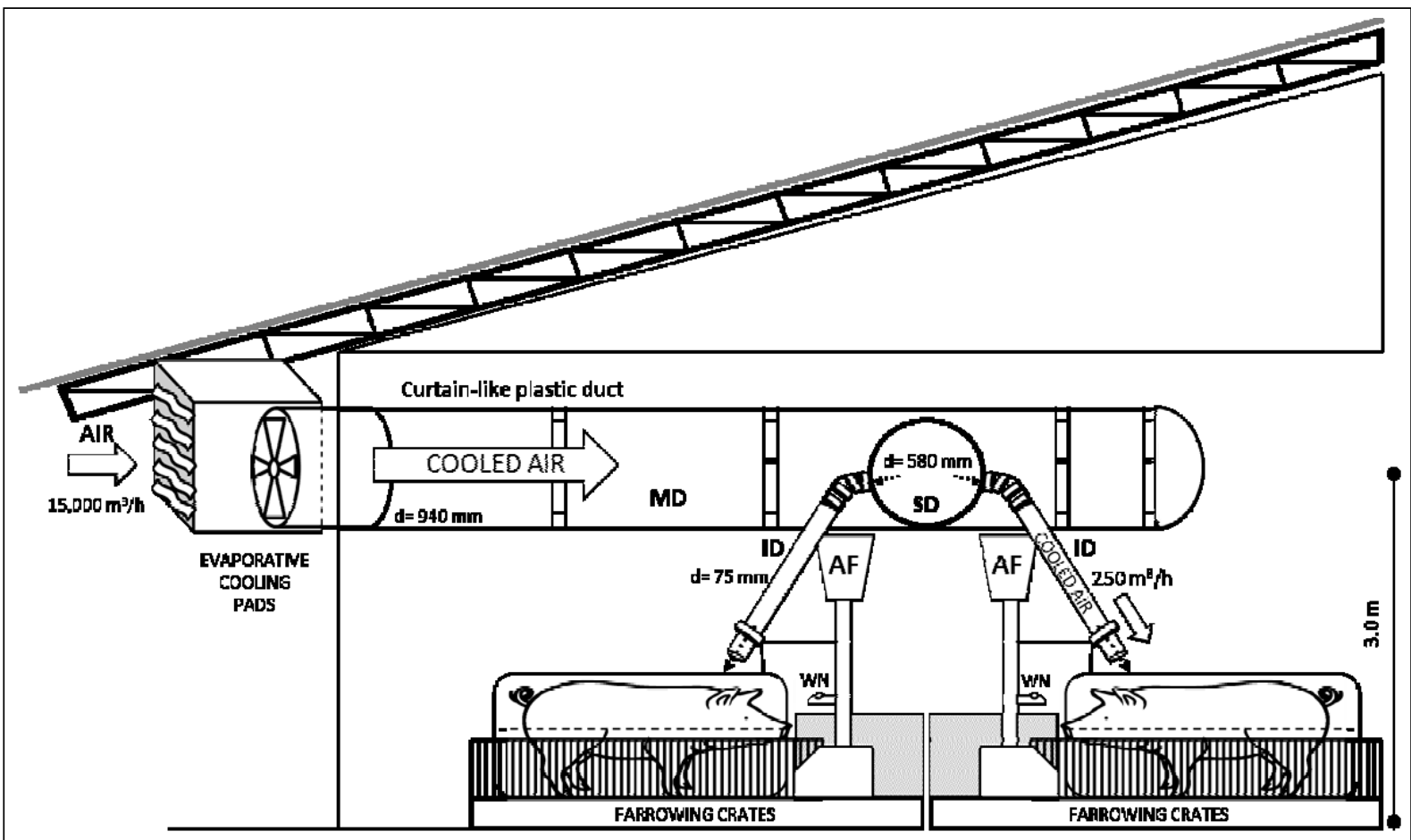

AF= Automatic Feeders; ID = Individual Duct; SD = Secondary Duct; MD = Main Duct; WN = Water Nipples

Figure 1 - Evaporative snout cooling system design and technological parameters. Inside the evaporative cooling pads area there is water flowing over the surface of the pad and it is responsible to turn the air that passes through the evaporative cooling pads in a cooled air. Due negative pressure, cooled air is into a curtain-like plastic duct and conducted to the interior of the farrowing rooms. Inside of the facilities, this duct is split on terminal individual ducts ending just above each farrowing crate, through which the air reaches the sow's neck region.

VFI started immediately after birth. The automatic feeders in the crates had a reservoir with capacity for approximately $8 \mathrm{~kg}$ of feed. The reservoir was filled manually, twice a day (at 7:00 a.m. and at 16:00 p.m). The amount of feed consumed and feed refusal were measured considering the amount of each 4 days (on days 4, 8, 12 and 16 of lactation). Between 12 and $36 \mathrm{~h}$ after birth, piglets were tattooed and crossfostered taking into account similar weights. Piglets were weighed at birth, after cross-fostering and at weaning (20.2 \pm 0.1 days of lactation). Piglets had no access to creep feed until weaning.

Rectal temperature (RT) of 24 females was monitored during the lactation period (12 sows in each system). The measurement was performed daily between 16:00 and 17:00 p.m., with a digital thermometer. Subsequent reproductive performance of all sows was evaluated and the following data were collected: weaning-to-oestrus interval (WOI), farrowing rate (FR), and the number of total piglets born (NTB).

The environmental temperature inside the rooms was measured with maximum and minimum thermometers Incoterm $^{\circledR}$ (DotDigital, Canela, RS,
Brazil) daily in the morning (at 8:00), noon (12:30) and afternoon (17:00). The RH was measured with a digital thermohygrometer Incoterm ${ }^{\circledR}$ (DotDigital, Canela, RS, Brazil).

All statistical analyses were performed using SAS software (SAS, 2005). RT and VFI were analysed as repeated measures using the MIXED procedure with a model containing fixed effects of treatment, parity order, day of lactation and the interaction between these factors. PWL during lactation, WOI, piglet weight and the number of piglets at weaning were also analysed using the MIXED procedure. The models contained fixed effects of treatment, parity order and the interaction between these two factors. For litter weight analysis the litter was considered the experimental unit. Litter weight at cross-fostering and the number of piglets at cross-fostering were used as covariates in the analyses of litter weight and number of weaned piglets, respectively. For temperature and $\mathrm{RH}$ data, the analysis was performed using the MIXED procedure for repeated measures. The model included fixed effects of treatments, the time of the 
day and the interaction between these two factors. The experimental period was included as a random effect in all the models of analysis. LSMeans were compared by Tukey-Kramer, considering the level of $5 \%$ as significant and between 5 and $10 \%$ as a trend. Data are presented as means \pm standard error of mean.

\section{RESULTS AND DISCUSSION}

Sows of both systems were exposed to temperatures above the TCZ, but RT was higher in traditional temperature control system (TTCS) $(\mathrm{P}<0.05)$ almost all entire period (Figure 2). In accord with these results other studies showed the same pattern (RENAUDEAU et al., 2003b; WILLIAMS et al., 2013).

Voluntary feed intake (VFI) was not affected $(\mathrm{P}>0.05)$ by the interactions between treatment, parity order and day of lactation. VFI was lower $(\mathrm{P}<0.05)$ in TTCS sows (Table 1). There was a gradual increase in VFI over the lactational period $(\mathrm{P}<0.05)$ which is also observed in other studies (MOSNIER et al., 2010ab; WILLIAMS et al., 2013). This pattern can be explained by a gastrointestinal limitation of sows, due to the feed restriction during the gestational phase, also by the fact that digestive tract needs time to adapt to an ad libitum feed offer (EISSEN et al., 2000) and can be related to the insulin resistance in primiparous sows or to the insulin-glucose ratio in multiparous sows (MOSNIER et al., 2010ab) at the beginning of lactation. Primiparous sows had lower $(\mathrm{P}<0.05)$ VFI than multiparous sows, regardless of the temperature control system used (Table 1).

Lower VFI observed in TTCS sows agrees with the negative effect of increasing temperature on sows VFI (QUINIOU \& NOBLET, 1999; RENAUDEAU et al., 2003a; WILLIAMS et al., 2013).

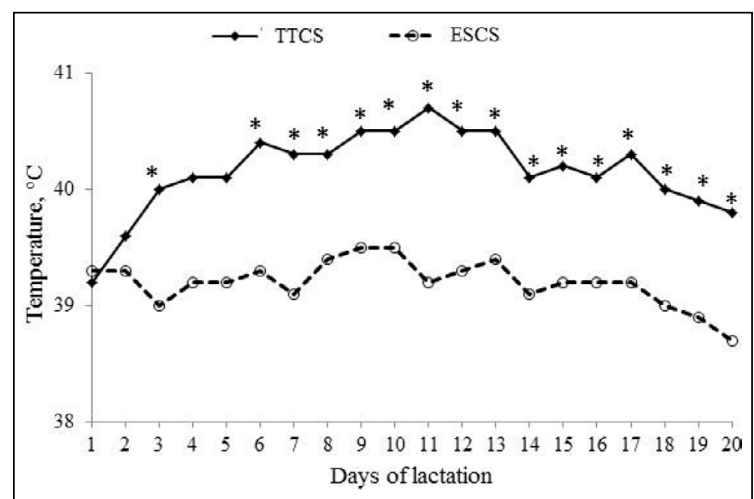

Figure 2 - Effect of temperature control systems on the rectal temperature of sows during lactation. TTCS = traditional temperature control system $(n=12)$. ESCS = evaporative snout cooling system $(\mathrm{n}=12)$. * Indicate statistical difference between the systems $(\mathrm{P}<0.05)$.
Table 1 - Voluntary feed intake (VFI) during lactation according to the temperature control system and the parity order of sows (LSmeans \pm SEM).

\begin{tabular}{lccc}
\hline Variables & TTCS $(\mathrm{n}=36)$ & ESCS $(\mathrm{n}=35)$ & Mean \\
\hline--------- VFI according to the lactation day, $\mathrm{kg} \mathrm{day}^{-1}-----------$ \\
4 & 3.8 & 4.2 & $4.0 \pm 0.16 \mathrm{x}$ \\
8 & 4.9 & 5.9 & $5.4 \pm 0.19 \mathrm{y}$ \\
12 & 5.2 & 6.3 & $5.7 \pm 0.16 \mathrm{y}$ \\
16 & 5.5 & 6.9 & $6.2 \pm 0.16 \mathrm{z}$ \\
Mean & $4.8 \pm 0.18 \mathrm{a}$ & $5.8 \pm 0.18 \mathrm{~b}$ & \\
-------------------- & \\
Primiparous & $3.8(\mathrm{n}=16)$ & $4.9(\mathrm{n}=16)$ & $4.4 \pm 0.19 \mathrm{x}$ \\
Multiparous & $5.8(\mathrm{n}=20)$ & $6.8(\mathrm{n}=19)$ & $6.3 \pm 0.17 \mathrm{y}$ \\
\hline
\end{tabular}

$a, b$ in the same row indicate statistical differences $(P<0.05)$.

$\mathrm{x}, \mathrm{y}, \mathrm{z}$ in the same column indicate statistical differences $(\mathrm{P}<0.05)$.

TTCS $=$ traditional temperature control system.

$\mathrm{ESCS}=$ evaporative snout cooling system.

According to BLACK et al. (1993), VFI decreases $0.17 \mathrm{~kg}$ per each increase of $1^{\circ} \mathrm{C}$ in the environmental temperature, when it is above $16^{\circ} \mathrm{C}$. Despite the fact that there was no difference between the two systems in the temperature inside the rooms $\left(25.8 \pm 0.3^{\circ} \mathrm{C}\right.$ vs. $26.1 \pm 0.3^{\circ} \mathrm{C} ; \mathrm{P}>0.05$; TTCS vs. ESCS, respectively), the lower body temperature of evaporative snout cooling system (ESCS) sows probably explains their higher VFI. Sows probably reduce their VFI in an attempt to decrease internal heat production (WILLIAMS et al., 2013). In addition to their gastrointestinal limitation (EISSEN et al., 2000), primiparous sows are more sensitive to high temperature compared to multiparous sows (BLACK et al., 1993).

PWL was not affected $(\mathrm{P}>0.05)$ by the interaction between treatment and parity order. The higher PWL in TTCS sows $(5.3 \pm 0.7 \%$ versus $2.2 \pm 0.7 \% ; \mathrm{P}<0.001)$ agrees with results of another study in which sows exposed to high temperatures lost more weight (QUINIOU \& NOBLET, 1999). Weight loss during lactation is common, mainly in hiperprolific sows, because VFI is not sufficient to attend the energetic demands for maintenance and milk production (EISSEN et al., 2003), and a mobilization of the body reserves is needed to fulfill the demands for milk production (KIM \& EASTER, 2001).

The number of piglets and litter weighted at cross-fostering were similar among systems $(12.8 \pm 0.1$ piglets per sow and $18.5 \pm 0.5 \mathrm{~kg}$, respectively). There was no difference $(\mathrm{P}>0.05)$ in the number of weaned piglets between systems or parity order classes (Table 2). The better growth performance of ESCS piglets confirms previous observations that heat 
Table 2 - Number of weaned piglets and litter weight at weaning according to the temperature control system and the parity order of sows (LSmeans \pm SEM) and weaning-to-oestrus interval (WOI), farrowing rate (FR) and total number of piglets born (NTB) according to the temperature control system (LSmeans \pm SEM).

\begin{tabular}{llllllll}
\hline Variables & \multicolumn{1}{c}{ TTCS } & N & ESCS & N & Primiparous & N & Multiparous \\
\hline Piglets weaned/sow & $11.5 \pm 0.27$ & 36 & $11.7 \pm 0.27$ & 35 & $11.8 \pm 0.28$ & 32 & $11.4 \pm 0.26$ \\
Litter weight at weaning, kg & $60.7 \pm 1.40 \mathrm{a}$ & 36 & $65.3 \pm 1.43 \mathrm{~b}$ & 35 & $61.6 \pm 1.52$ & 32 & $64.4 \pm 1.33$ \\
WOI - Primiparous sows, days & $10.9 \pm 1.3 \mathrm{cx}$ & 27 & $7.1 \pm 1.2 \mathrm{~d}$ & 26 & - & 39 & - \\
WOI - Multiparous sows, days & $4.7 \pm 0.7 \mathrm{y}$ & 81 & $5.0 \pm 0.7$ & 80 & - & - \\
FR, \% & 79.0 & 105 & 80.7 & 109 & - & - \\
NTB & $10.9 \pm 0.6 \mathrm{e}$ & 88 & $12.0 \pm 0.5 \mathrm{f}$ & 83 & - & - \\
\hline
\end{tabular}

$a, b$ in the same row indicate statistical differences $(\mathrm{P}<0.05)$.

$c, d$ in the same row indicate statistical differences $(\mathrm{P}<0.05)$.

$\mathrm{e}, \mathrm{f}$ in the same row indicate a tendency to be statistically different $(\mathrm{P}=0.095)$.

$\mathrm{x}, \mathrm{y}$ in the same column indicate statistical differences $(\mathrm{P}<0.05)$.

TTCS $=$ traditional temperature control system.

$\mathrm{ESCS}=$ evaporative snout cooling system.

WOI $=$ weaning-to-oestrus interval.

$\mathrm{FR}=$ farrowing rate.

$\mathrm{NTB}=$ total piglets born.

stressed sows have piglets with lower weaning weight than sows exposed to a TCZ (WILLIAMS et al., 2013).

WOI is not necessarily influenced by high temperatures (RENAUDEAU et al., 2003a; WILLIAMS et al., 2013), but it is affected by higher PWL (HOVING et al., 2012), showing that environmental temperature can have an indirect effect on this variable. Since PWL of primiparous sows was higher $(6.3 \pm 0.9 \%$ versus $1.2 \pm 0.6 \%, \mathrm{P}<0.0001)$ than multiparous sows, this aspect probably explains the beneficial effect of the ESCS in reducing the WOI (Table 2). Within the TTCS, WOI was longer $(\mathrm{P}<0.05)$ in primiparous than in multiparous sows. FR was similar between systems $(\mathrm{P}>0.05$; Table 2$)$. The subsequent litter size was neither affected by the parity order nor by the interaction between treatment and parity order $(\mathrm{P}>0.05)$. NTB tended to be higher $(\mathrm{P}=0.095)$ in ESCS than in TTCS sows (Table 2).

Neither temperature nor humidity values were affected $(\mathrm{P}>0.05)$ by the interaction between treatment and the moment of the day. There were no differences $(\mathrm{P}>0.05)$ in average and maximum temperature and in humidity between TTCS and ESCS.

\section{CONCLUSION}

In conclusion, evaporative snout cooling system promotes the reduction of rectal temperature, increase voluntary feed intake, reduce sow's weight loss and improve growth performance of litters.
A beneficial effect of this system on reducing the weaning-to-oestrus interval occurs in primiparous but not in multiparous sows.

\section{ACKNOWLEDGEMENTS}

The authors are grateful to Conselho Nacional de Desenvolvimento Científico e Tecnológico (CNPq), Coordenação de Aperfeiçoamento de Pessoal de Nível Superior (CAPES) and Agroceres PIC ${ }^{\circledR}$ for the financial support and to Master Company for providing the facilities to perform this study.

\section{REFERENCES}

BARBARI, M.; CONTI, L. Use of different cooling systems by pregnant sows in experimental pen. Biosystems Engineering, v.103, p.239-244, 2009. Available from: $<$ http://www.sciencedirect. com/science/article/pii/S1537511009000658>. Accessed: Nov. 15, 2014. doi: 10.1016/j.biosystemseng.2009.02.016.

BLACK, J.L. et al. Lactation in the sow during heat stress. Livestock Science, v.35, p.153-170, 1993. Available from: <http:// www.sciencedirect.com/science/article/pii/030162269390188N >. Accessed: Nov. 15, 2014. doi: 10.1016/0301-6226(93)90188-N.

BLOEMHOF, S. et al. Sow line differences in heat stress tolerance expressed in reproductive performance traits. Journal of Animal Science, v.86, p.3330-3337, 2008. Available from: $<$ http://www. journalofanimalscience.org/content/86/12/3330.full $>$. Accessed: Nov. 15, 2014. doi: 10.2527/jas.2008-0862.

EISSEN, J.J. et al. Sow factors affecting voluntary feed intake during lactation. Livestock Science, v.64, p.147-165, 2000. Available from: <http:/www.sciencedirect.com/science/article/ pii/S0301622699001530>. Accessed Nov. 15, 2014. doi:10.1016/ S0301-6226(99)00153-0. 
EISSEN, J.J. et al. The importance of a high feed intake during lactation of primiparous sows nursing large litters. Journal of Animal Science, v.81, p.594-603, 2003. Available from: $<$ http://www.journalofanimalscience.org/content/81/3/594.full. pdf + html $>$. Accessed: Nov.1 2014.

HOVING, L.L. et al. Lactation weight loss in primiparous sows: consequences for embryo survival and progesterone and relations with metabolic profiles. Reproduction in Domestic Animals, v.47, p.1009-1016, 2012. Available from: <http://www.ncbi. nlm.nih.gov/pubmed/22420822>. Accessed Nov. 15, 2014. doi: 10.1111/j.1439-0531.2012.02007.x.

KIM, S.W.; EASTER, R.A. Nutrient mobilization from body tissues as influenced by litter size in lactating sows. Journal of Animal Science, v.79, p.2179-2186, 2001. Available from: $<$ http://www.journalofanimalscience.org/content/79/8/2179.full. pdf>. Accessed: Nov. 1, 2014.

MARTINS, T.D.D. et al. Posture and behavior of sows in lactating maintained under conditions of high environmental temperature. Revista Biotemas, v.21, p.137-145, 2008. Available from: $<\mathrm{https}: /$ periodicos. ufsc.br/index.php/biotemas/article/view/2175-7925.2008v21n4p137>. Accessed: Nov. 1, 2014. doi: 10.5007/21757925.2008v21n4p137.

MOSNIER, E. et al. Reduced feed intake of lactating primiparous sows is associated with increased insulin resistance during the peripartum period and is not modified through supplementation with dietary tryptophan. Journal of Animal Science, v.88, p.612-625, 2010a. Available from: <http://www.ncbi.nlm.nih.gov/pubmed/19855001>. Accessed: Nov. 15, 2014. doi: 10.2527/jas.2008-1768.

MOSNIER, E. et al. The metabolic status during the peri partum period affects the voluntary feed intake and the metabolism of the lactating multiparous sow. Livestock Science, v.127, p.127-136, 2010b. Available from: <http://www.livestockscience.com/article/
S1871-1413\%2809\%2900261-3/abstract>. Accessed: Nov. 1 2014. doi: 10.1016/j.livsci.2009.06.023.

QUINIOU, N.; NOBLET, J. Influence of high ambient temperatures on performance of multiparous lactating sows. Journal of Animal Science, v.77, p.2124-2134, 1999. Available from: <http://www. ncbi.nlm.nih.gov/pubmed/10461991>. Accessed: Nov. 1, 2014.

RENAUDEAU, D. et al. Effects of dietary fiber on performance of multiparous lactating sows in a tropical climate. Journal of Animal Science, v.81, p.717-725, 2003a. Available from: $<$ http://www.ncbi. nlm.nih.gov/pubmed/12661652>. Accessed: Nov. 1, 2014.

RENAUDEAU, D. et al. Effect of ambient temperature on mammary gland metabolism in lactating sows. Journal of Animal Science, v.81, p.217-231, 2003b. Available from: <http:// www. ncbi.nlm.nih.gov/pubmed/12597393>. Accessed: Nov. 15, 2014.

SAS INSTITUTE. SAS User's guide. Cary, 2005. Release 9.1.3.

THAKER, M.Y.C.; BILKEI, G. Lactation weight loss influences subsequent reproductive performance of sows. Animal Reproduction Science, v.88, p.309-318, 2005. Available from: <http://www.ncbi. nlm.nih.gov/pubmed/15985345>. Accessed: Nov. 15, 2014.

TOLON, Y.B.; NÄÄS, I.A. Evaluation of types of ventilation in swine maternity. Engenharia Agrícola, v.25, p.565-574, 2005. Available from: <http://www.scielo.br/scielo.php?script=sci_artte xt\&pid=S0100-69162005000300001>. Accessed: Nov. 15, 2014. doi: 10.1590/S0100-69162005000300001.

WILLIAMS, A.M. et al. Effects of a controlled heat stress during late gestation, lactation, and after weaning on thermoregulation, metabolism, and reproduction of primiparous sows. Journal of Animal Science, v.91, p.2700-2714, 2013. Available from: $<$ http://www.ncbi.nlm.nih.gov/pubmed/23508026>. Accessed: Nov. 15, 2014. doi: 10.2527/jas.2012-6055. 